University of Nebraska - Lincoln

DigitalCommons@University of Nebraska - Lincoln

Faculty Publications from the Harold W. Manter Laboratory of Parasitology

6-1-2008

\title{
Parasites as Probes for Prehistoric Human Migrations?
}

Adauto Araújo

Instituto Oswaldo Cruz, adauto@fiocruz.br

Karl J. Reinhard

University of Nebraska - Lincoln, kreinhard1@mac.com

Luiz Fernando Ferreira

Instituto Oswaldo Cruz

Scott Lyell Gardner

University of Nebraska - Lincoln, slg@unl.edu

Follow this and additional works at: https://digitalcommons.unl.edu/parasitologyfacpubs

Part of the Parasitology Commons

Araújo, Adauto; Reinhard, Karl J.; Ferreira, Luiz Fernando; and Gardner, Scott Lyell, "Parasites as Probes for Prehistoric Human Migrations?" (2008). Faculty Publications from the Harold W. Manter Laboratory of Parasitology. 49.

https://digitalcommons.unl.edu/parasitologyfacpubs/49

This Article is brought to you for free and open access by the Parasitology, Harold W. Manter Laboratory of at DigitalCommons@University of Nebraska - Lincoln. It has been accepted for inclusion in Faculty Publications from the Harold W. Manter Laboratory of Parasitology by an authorized administrator of DigitalCommons@University of Nebraska - Lincoln. 


\title{
Opinion: \\ Parasites as Probes for Prehistoric Human Migrations?
}

\author{
Adauto Araújo일 ${ }^{1}$ Karl J. Reinhard ${ }^{2}$, Luiz Fernando Ferreira ${ }^{1}$ and Scott L. Gardner ${ }^{3}$ \\ ${ }^{1}$ Fundação Oswaldo Cruz/Escola Nacional de Saude Publica; Rua Leopoldo Bulhoes 1480, Rio de Janeiro 2104-210, RJ, Brazil \\ 2710 Hardin Hall, School of Natural Resources, University of Nebraska, Lincoln, NE 68583-0987, USA \\ ${ }^{3}$ Harold W. Manter Laboratory of Parasitology, W 529 Nebraska Hall, University of Nebraska-Lincoln, Lincoln, NE 68588-0514 USA \\ (Corresponding author: S.L. Gardner, slg@unl.edu).
}

\begin{abstract}
Host-specific parasites of humans are used to track ancient migrations. Based on archaeoparasitology, it is clear that humans entered the New World at least twice in ancient times. The archaeoparasitology of some intestinal parasites in the New World points to migration routes other than the Bering Land Bridge. Helminths have been found in mummies and coprolites in North and South America. Hookworms (Necator and Ancylostoma), whipworms (Trichuris trichiura) and other helminths require specific conditions for life-cycle completion. They could not survive in the cold climate of the northern region of the Americas. Therefore, humans would have lost some intestinal parasites while crossing Beringia. Evidence is provided here from published data of pre-Columbian sites for the peopling of the Americas through trans-oceanic or costal migrations.
\end{abstract}

\section{Ancient migrations to the Americas}

The timing of the arrival of humans in the New World has been the focus of a long-standing and intense debate with different scientific disciplines contributing their own perspectives to the question. Some challenge the widely accepted hypothesis that populations of prehistoric humans crossed into the Americas when climate conditions created the Bering Land Bridge at least 13,000 years ago. However, people could have reached the Americas more than 7,000 years ago using alternative routes, thus avoiding the extreme cold of the Arctic. From the parasitological perspective, unequivocal evidence shows that populations of pre-historic humans were infected by several host-specific intestinal parasites found in both North and South American archaeological sites [1]. The life cycle of these exclusively human parasites could not have been maintained among human groups during the crossing from Siberia to Alaska via Beringia.

\section{Heirloom parasites and souvenir parasites}

Some infectious agents of human disease have coevolved with species in the Homo lineage for over 400,000 years [25]. It is clear that our most common parasites had a concomitant origin with earlier species in the human evolutionary line and these coevolutionary events certainly date to an early common ancestor of humans and apes. These long-term, coevolved parasites are sometimes called 'heirloom parasites' $[2,6]$ or, in the parlance of evolutionary bi- ology, parasites that are biological symplesiomorphies [7]. As humans evolved, their heirloom parasites evolved with them. This appears to be the case for both Trichuris trichiura (whipworm) and Enterobius (pinworm) [2-4]. The evolution and diversification of Enterobius resulted in two species in humans, Enterobius vermicularis and Enterobius gregorii. As pointed out by Cameron in 1958 [8], Ascaris lumbricoides (intestinal roundworm) and Ancylostoma duodenale (hookworm) are also human heirloom parasites $[9,10]$.

Humans have acquired a myriad of other parasites during their long biological and social history. Sometimes called souvenir parasites [6,11], these include species that occur in humans commonly, arriving through host-switching from other animal species.

Animal domestication might have provided opportunities for parasites to colonize humans. This was considered the origin of two species of taeniid tapeworms in humans that use cattle and pigs as intermediate hosts. However, phylogenetic systematic studies show that association of beef tapeworm in humans (Taenia saginata) pre-dates the development of the domestication of cattle (Bos spp.) or swine (Sus scrofa) [12,13].

Many heirloom parasites evolved with humans in the Old World tropical and subtropical regions. Therefore, it is not surprising to find whipworm, pinworm and hookworm eggs in ancient Old World archaeological sites [1]. These parasites accompanied early Homo groups as they migrated out of Africa to other tropical regions, persisting in their hosts as long as environmental conditions enabled transmission. Climate and soil temperature are limiting factors for human hookworm and whipworm, being hostspecific and without intermediate hosts. High soil moisture and moderate temperature are necessary for eggs or larvae to reach the infective stage. By contrast, eggs of E. vermicularis are infective as soon as they are expelled from female worms; in the external environment, they can infect humans immediately through contaminated hands, soil, water, any kind of object or as an aerosol. Therefore, pinworm eggs are not dependent on climate conditions [4].

All three nematodes have been found in North and South American archaeological material. However, because they are dependent on a habitation for transmission, only pinworms could have accompanied humans during the crossing of Beringia [14]. Hookworm and whipworm have biological requirements that could not have been met in Beringia 
and, today, these species do not occur in traditional populations of the Artic region, although pinworms do [15].

In this article, how archaeological findings of these parasites contribute to the debate on the peopling of the New World is shown.

\section{Whipworms and hookworms}

The whipworm, T. trichiura, is essentially a subtropical parasite; females lay unembryonated eggs in the intestine, which pass in host feces. The eggs require three weeks to reach infective stage in optimal conditions: warm, moist, shaded soils. Hookworms (A. duodenale and Necator americanus) also pass eggs with feces, however, the eggs hatch in the soil and the emerging free-living, bacterial-feeding juveniles pass through three consecutive juvenile stages before penetrating the skin of the human host. The development of larvae depends on warm, moist, shaded soils. Such conditions could not have been met in Beringia and whipworm and hookworm have never been reported in Inuit, Yupik or other arctic and subarctic peoples living a traditional lifestyle [15-23]. Despite this, there is abundant evidence of the presence of these parasites in prehistoric humans in temperate and tropical parts of the New World.

The occurrence of both whipworm and hookworm eggs in human archaeological material, including coprolites collected from mummies, was reviewed recently [1]. Continuous association of whipworm and ancient humans in South America is evident beginning at least 6,000 years ago. Whipworm eggs were found in human coprolites and in the intestines of mummies in Brazil, Peru and Chile [2427]. In North America, whipworm eggs have been found in coprolites from the prehistoric site of Elden Pueblo (AZ, USA) aged, conservatively, approximately 800 years old [28-30]. Prehistoric infection with these parasites shows a North to South American distribution [31] and hookworm infection was present in ancient inhabitants of South America dated to 7,000 years BP (before present) [32].

There is no prehistoric record of whipworm or hookworm infection in the temperate, subarctic or arctic regions of North America; however, in historic times, whipworm occurred commonly in invading human immigrants [30] and has been reported from the latrines in Skagway, Alaska in the 1800s [33]. However, this occurred in the urban environments of Euro-American towns with inadequate sanitation and crowded conditions that enabled rapid transfer of parasites to geographically new areas by ships, trains and road traffic. The development of crowded unsanitary towns enabled whipworm to flourish far to the north of the natural prehistoric range of the parasite.

The presence of both whipworm and hookworm in humans inhabiting the prehistoric Americas requires an explanation [34]. These parasites are not endemic to the arctic and subarctic, yet are found in human remains of prehistoric tropical and subtropical America. Alternative reconstructions of the migration of prehistoric hookworms and whipworms into the Americas have been considered [3438]. Because these worms are host-specific, they necessarily entered the New World through the migration of human

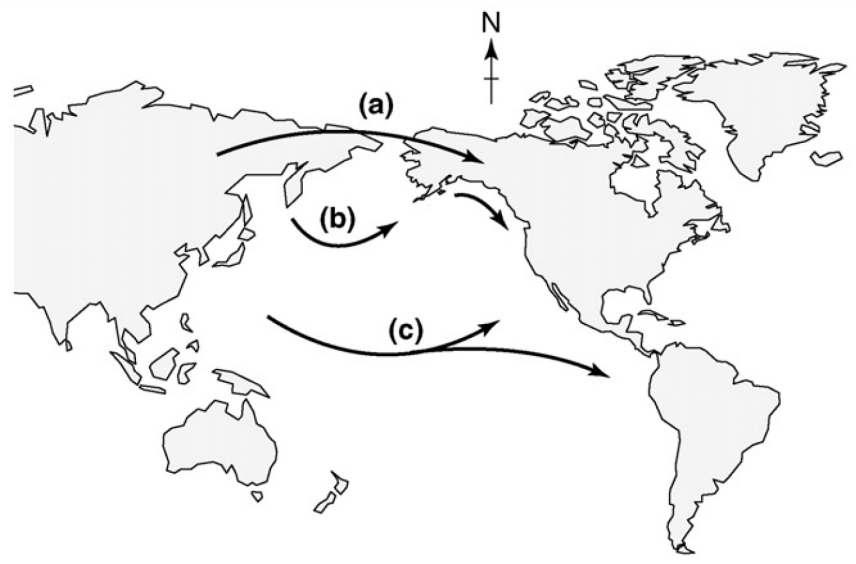

Figure 1. Three general migration routes of humans in prehistory have been hypothesized from Asia to the Americas. (a) Represents the longest-standing hypothesis of a migration route through Beringia and into North America at the time of low sea level and glacial maximum; this route is not supported by consensus of parasite probes from archaeological sites because only pinworms could survive in people in the Arctic. Parasite probe data are consistent with (b) a coastal migration or (c) a trans-pacific migration (a long-standing hypothesized route) that is also consistent with parasite data and could have happened quickly, thus ensuring a rapid parasite transfer to the new world.

hosts. However, because the extracorporeal maturation of the parasites requires warm conditions, migration routes through Beringia and into the center of the North American continent were discounted. Instead, transpacific migration or a coastal migration, possibly through the sub-Arctic region, was proposed (Figure 1) [34-38].

\section{Strongyloides stercoralis}

The presence of another parasite, S. stercoralis (threadworm), in prehistoric New World humans defied explanation for many years $[29,39,40]$. Threadworm has multiple variations in its life cycle: female juvenile worms infect humans either by burrowing through the skin or when the infective stage is swallowed. After migrating through tissues, juvenile females molt and reach maturity in the intestine and produce eggs by parthenogenesis. Once laid, the eggs hatch within the host intestine. Most juveniles are passed with feces and go through several molts in the soil. However, some juveniles remain in the intestine, where they molt to the infective stage and penetrate the host intestine through autoinfection. Autoinfections can thus maintain the nematode in one person for the lifetime of that person $[29,39,40]$. Endemic in tropical and subtropical regions presently, S. stercoralis has been found in three prehistoric sites in southwest North America [29,39,40]. Like whipworm and hookworm, migration of threadworm into the New World cannot be explained easily by a migration through Beringia because this parasite is restricted to warm climates by its life-cycle requirements in soil $[29,39]$.

\section{Enterobius vermicularis}

Pinworm eggs have been found in American archaeological sites and Enterobius vermicularis has been identified from prehistoric populations of American Indians [30]. More than most parasite lineages, pinworm phylogeny shows 
tight congruence with primate phylogeny [2-4,40,41]. This shows that cophylogeny occurred between pinworms and their primate hosts. Genetic drift occurred in pinworms as human populations diverged in geographical space, resulting in the emergence of at least one new species, E. gregorii in humans [42]. The possibility that genetic drift occurred in pinworms in different parts of the Americas was explored recently $[43,44]$. It was reasoned that, if multiple populations of humans arrived in the Americas using different migration routes, then genetic drift might be reflected in the DNA sequences of ancient pinworms. In other words, a migration of people through Beringia might have brought with them a different genotype of E. vermicularis relative to humans migrating with parasites from different regions. Two different E. vermicularis genetic sequences have been found in prehistoric coprolites from the Americas, which do not reject the genetic drift hypothesis [44].

\section{Evidence of migrations through a complex of parasites}

Parasite species found in humans today reflect parasites inherited from ancestors as well as parasites acquired during biological and social human evolution. In the past, authors who criticized parasitological evidence of ancient human migrations addressed only one parasite [45]. When hookworm, whipworm and threadworm are considered together, their value in tracing human migrations becomes greater. An alternative was proposed, arguing that hookworm has hypobiotic potential, which heightened its ability to migrate through an arctic route [46]. However, this argument fails when one considers the fact that humans did not simply travel through Beringia and probably dispersed slowly through the area over many hundreds of years.

The argument of hypobiosis does not hold true for whipworms. Even the durable whipworm eggs cannot survive cold conditions. The autoinfection properties of threadworm can enable this parasite to persist in an individual for many years after initial infection; however, this rare phenomenon does not explain adequately how the parasite persisted through arctic migrations.

The presence of three tropical and subtropical parasites (Trichuris, Strongyloides and Ancylostoma) in prehistoric humans in the New World and the fact that all require moisture and warmth to develop indicates that a Beringian crossing would not be possible for these parasites. However, these conditions could have been met in the microhabitats encountered in a coastal migration using watercraft. Parasitological evidence also points to an alternative route to the New World during prehistoric times. People, along with their intestinal parasite stowaways, could have reached the Pacific coast by crossing the sea in boats. They might not have started new colonies, rather transferred infections to people already living in the Americas. Because these people were probably of the same Asiatic origin, they left no genetic trace, only their intestinal parasites. This would have occurred more than 7,000 years ago based on radiocarbon method $[37,38]$. Differences in pinworm genome sequences recovered from North American and Chilean archaeological sites $[43,44]$ point to different origins of pinworm parasite strains and can be explained by alternative prehistoric migration routes. Therefore, based on the evidence of para- sites, a coastal migration of humans occurred in addition to the migration through the Bering Land Bridge.

\section{Concluding remarks}

How did these parasites enter the New World? Montenegro et al. [47] proposed that a coastal migration could have taken place and was a mechanism by which a tropical parasite complex could have migrated rapidly from the Old World to the Americas. The distributions of hookworm, whipworm and threadworm in the prehistoric Americas are best explained by Montenegro's coastal migration model [47]. He used archaeological hookworm findings, climate data and paleoclimate modeling to test whether peoples migrating from areas compatible to hookworm in Asia across Beringia and into North America could have crossed the distance fast enough to provide an explanation for hookworm in the prehistoric Americas [47]. A model was proposed where, before European contact, all inhabitants of the Americas, except for the Arctic and Subarctic, descended from migrants into the continents by a terrestrial interior route across the Bering Land Bridge at approximately 13,000 years BP.

The model shows that people migrating across Beringia into North America could not have crossed the hookwormhostile environments fast enough to introduce hookworm into the ancient Americas. The establishment of hookworm into the Americas through land migration at approximately 13,000 years BP could have happened only under extraordinary circumstances and, even then, would have required displacement rates that appear to have no parallel in the archaeology of the continent. Conclusions indicate that, although the Clovis migration across the Bering Land Bridge might have been the first, it was not the only human migration into the Americas. Other migrations could have been coastal [47] or, in our opinion, they could have been transoceanic migrations [32].

We would like to call the attention of scientists interested in the peopling of the Americas to the data derived from paleoparasitology. Parasites are subject to the same evolutionary phenomena, including selection, extinction and colonization events as humans and other organisms. Therefore, the very specific human parasites mentioned here appear to be excellent probes that can shed light on past human migrations.

In a broad sense, the prehistory of human-parasite migrations is relevant to the question of emerging infectious diseases in times of global climate change [48]. The prehistoric parasites of ancient humans persisted during the early coastal or trans-oceanic migration from Polynesia [32] and eventually colonized two continents. Inaddition, humans acquired parasites endemic to the Americas [30,49]. Thus, the movement of humans both introduced new parasites to new places and introduced new parasites to humans as they entered these new places.

\section{Acknowledgments}

The authors are supported by CNPq (Brazilian Research Council-2003-2006), Fulbright Commission and PAPES/ Fiocruz (Support for Health Strategic Research, Fundação Oswaldo Cruz - 2006) and by the Harold W. Manter Laboratory of Parasitology development fund. 


\section{References}

1 Gonçalves, M.L. et al. (2003) Human intestinal parasites in the past: new findings and a review. Mem. Inst. Oswaldo Cruz 98, 103-118.

2 Brooks, D.R. and Ferrao, A.L. (2005) The historical biogeography of coevolution: emerging infectious diseases are evolutionary accidents waiting to happen. J. Biogeogr. 32, 1291-1299.

3 Folinsbee, K.E. and Brooks, D.R. (2007) Early hominoid biogeography: pulses of dispersal and differentiation. J. Biogeogr. 34, 383-397.

4 Hugot, J.P. et al. (1999) Human enterobiasis in evolution: origin, specificity and transmission. Parasite 6, 201-208.

5 Wirth, T. et al. (2005) Deciphering host migrations and origins by means of their microbes. Mol. Ecol. 14, 3289-3306.

6 Barrett, R. et al. (1998) Emerging and re-emerging infectious diseases: the third epidemiologic transition. Ann. Rev. Anthropol. 27, 247-271.

7 Brooks, D.R. and McLennan, D.A. (2002) The Nature of Diversity: an Evolutionary Voyage of Discovery. University of Chicago Press.

8 Cameron, T.W. (1958) Parasites of animals and human disease. Ann. N. Y. Acad. Sci. 70, 564-573.

9 Anderson, T.J. and Jaenike, J. (1997) Host specificity, evolutionary relationships and macrogeographic differentiation among Ascaris populations from humans and pigs. Parasitology 115, 325-342.

10 Le, T.H. et al. (2000) Mitochondrial genomes of human helminths and their use as markers in population genetics and phylogeny. Acta Trop. 77, 243-256.

11 Kliks, M.M. (1983) Paleoparasitology: on the origins and impact of human-helminth relationships. In: Human Ecology and Infectious Disease (Croll, N.A. and Cross, J.H., eds), pp. 291-313, AcademicPress.

12 Hoberg, E.P. et al. (2001) Out of Africa: origins of the Taenia tapeworms in humans. Proc. Biol. Sci. 268, 781-787.

13 Hoberg, E.P. (2006) Phylogeny of Taenia: species definitions and origins of human parasites. Parasitol. Int. 55, S23-S30.

14 Araújo, A. and Ferreira, L.F. (1995) Oxiuríase e migrações préhistóricas (Oxiuriasis and prehistoric migrations). Hist. Ci. Saúde Manguinhos 2, 99-109.

15 Brown, M. et al. (1948) Intestinal parasites of Eskimos on Southampton Island, Northwest Territories. Can. J. Public Health 39, 451-454.

16 Arh, I. (1960) Fish tapeworm in Eskimos in the Port Harrison area, Canada. Can. J. Public Health 51, 268-271.

17 Curtis, M.A. and Bylund, G. (1991) Diphyllobothriasis: fish tapeworm disease in the circumpolar North. Arctic Med. Res. 50, 18-25.

18 Curtis, M.A. et al. (1988) Parasitic zoonoses in relation to fish and wildlife harvesting by Inuit communities in Northern Que'bec, Canada. Arctic Med. Res. 47, 693-696.

19 Desrochers, F. and Curtis, M.A. (1987) The occurrence of gastrointestinal helminths in dogs from Kuujjuaq (Fort Chimo), Québec, Canada. Can. J. Public Health 78, 403-406.

20 Eckert, J. and Hiepe, T. (1998) Parasiten in Nahrungsketten. Nova Acta Leopold. 79, 99-120.

21 Hitchcock, D.J. (1950) Parasitological study on the Eskimos in the Bethel area of Alaska. J. Parasitol. 36, 232-234.

22 Rausch, R.L. and Hilliard, D.K. (1970) Studies on the helminth fauna of Alaska. XLIX. The occurrence of Diphyllobothrium latum (Linnaeus, 1758) (Cestoda: Diphyllobothriidae) in Alaska with notes on other species. Can. J. Zool. 48, 1201-1219.

23 Rausch, R.L. et al. (1967) Helminths in Eskimos in Western Alaska, with particular reference to Diphyllobothrium infection and anaemia. Trans. R. Soc. Trop. Med. Hyg. 61, 351-357.

24 Pizzi, T. and Schenone, H. (1954) Allazgo de huevos de Trichuris trichiura en un cuerpo arqueológico incaico. Bol. Chil. Parasitol. 9, 73-75.

25 Ferreira, L.F. et al. (1980) Finding of helminth eggs in human coprolites from Unai, Minas Gerais, Brazil. Trans. R. Soc. Trop. Med. Hyg. $76,798-800$.
26 Ferreira, L.F. et al. (1983) The finding of helminth eggs in a Brazilian mummy. Trans. R. Soc. Trop. Med. Hyg. 77, 65-67.

27 Patrucco, R. et al. (1983) Parasitological studies of coprolites of preHispanic Peruvian populations. Curr. Anthropol. 24, 393-394.

28 Hevly, R.H. et al. (1979) Comparative effects of climate change, cultural impact and volcanism in the paleoecology of Flagstaff, Arizona, A.D. 900-1300. In: Volcanic Activity and Human Ecology (Sheets, P.D. and Grayson, D.K., eds), pp. 487-493, Academic Press.

29 Reinhard, K.J. et al. (1987) Helminth remains from prehistoric Indian coprolites on the Colorado Plateau. J. Parasitol. 73, 630-639.

30 Reinhard, K.J. (1990) Archaeoparasitology in North America. Am. J. Phys. Anthropol. 82, 145-162.

31 Reinhard, K. et al. (2001) American hookworm antiquity. Med. Anthropol. 20, 96-101.

32 Araújo, A. et al. (1988) Hookworm and the peopling of the Americas. Cad. Saúde Publica 2, 226-233.

33 Cooper, D.C. (1998) Archaeological Investigations in Skagway, Residential Life on Block 39, Vol. 6, p. 21, U.S. Department of Interior, National Park Service, Klondike Gold Rush National Historical Park, Skagway, AK.

34 Reinhard, K.J. (1992) Parasitology as an interpretative tool in archaeology. Am. Antiq. 57, 231-245.

35 Araújo, A. et al. (1981) A contribution to the study of helminth findings in archaeological material in Brazil. Rev. Bras. Biol. 41, 873-881.

36 Confalonieri, U. et al. (1991) Intestinal helminths in lowland South American Indians: some evolutionary interpretations. Hum. Biol. $63,863-873$

37 Ferreira, L.F. and Araújo, A. (1996) On hookworms in the Americas and trans-pacific contact. Parasitol. Today 12, 454.

38 Reinhard, K.J. et al. (2001) American hookworm antiquity. Med. Anthropol. 20, 97-101.

39 Reinhard, K.J. (1985) Strongyloides stercoralis in the prehistoric Southwest. In Health and Disease in the Prehistoric Southwest (Merbs, C.F. and Milner, R.J., eds), pp. 234-242, Arizona State University.

40 Dorris, M. et al. (2002) Molecular phylogenetic analysis of the genus Strongyloides and related nematodes. Int. J. Parasitol. 32, 1507-1517.

41 Sorci, G. et al. (2003) Correlated evolution between host immunity and parasite life histories in primates and oxyurid parasites. Proc. Biol. Sci. 270, 2481-2484.

42 Hugot, J.P. (1999) Primates and their pinworm parasites: the Cameron hypothesis revisited. Syst. Biol. 48, 523-546.

43 Iniguez, A.M. et al. (2002) Enterobius vermicularis: specific detection by amplification of an internal region of $5 \mathrm{~S}$ ribosomal RNA intergenic spacer and trans-splicing leader RNA analysis. Exp. Parasitol. 102, 218-222.

44 Iniguez, A.M. et al. (2006) SL1 RNA gene recovery from Enterobius vermicularis ancient DNA in pre-Columbian human coprolites. Int. J. Parasitol. 36, 1419-1425.

45 Fuller, K. (1997) Hookworm: not a pre-Columbian pathogen. Med. Anthropol. 17, 297-308.

46 Hawdon, J.M. and Johnston, S.A. (1996) Hookworms in the Americas: an alternative to trans-Pacific contact. Para. Today 12, 72-74.

47 Montenegro, A. et al. (2006) Parasites, paleoclimate and the peopling of the Americas: Using the hookworm to time the Clovis migration. Curr. Anthropol. 47, 193-200.

48 Brooks, D.R. and Hoberg, E.P. (2007) How will global climate change affect host-parasite assemblages? Trends Para. 23, 571-574.

49 Sianto, L. et al. (2005) The finding of Echinostoma pp. (Trematoda: Digenea) and hookworm eggs in coprolites collected from a Brazilian mummified body dated of $600-1,200$ years before present. $J$. Parasitol. 91, 972-975. 